\section{THE EFFECTS OF VARIOUS OPENING SIZES AND CONFIGURATIONS TO AIR FLOW DISPERSION AND VELOCITY IN CROSS- VENTILATED BUILDING}

\author{
Wardah Fatimah Mohammad Yusoff*
}

Department of Architecture and Built Environment, Faculty of Engineering and Built Environment, Universiti Kebangsaan Malaysia, 43600 Bangi, Selangor, Malaysia
Article history

Received

7 January 2020

Received in revised form

27 April 2020

Accepted

30 April 2020

Published online

22 June 2020

\section{*Corresponding author wardahyusoff@ukm.edu.my}

\section{Graphical abstract}

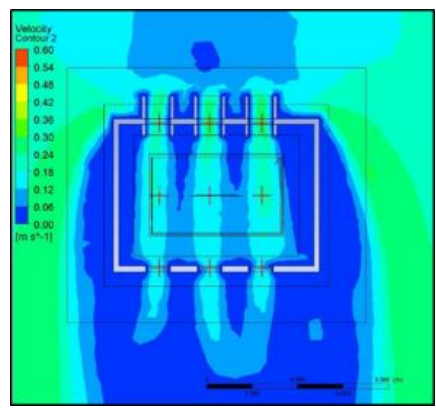

\begin{abstract}
The application of natural cross-ventilation in buildings located in the area where the wind speed is low is such a challenge. In hot and humid climate, sufficient air velocity is necessary in providing thermal comfort. Hence, this study intends to investigate the possibility of enhancing the indoor air velocity and flow distribution by employing the Venturi effect at the openings. Two research methods were applied namely field measurement and numerical simulation. The field measurement was executed at a single zone cross-ventilated building. Its purpose is to validate the numerical simulation steps and procedures. Meanwhile, investigations of the air velocity and flow distribution were conducted using ANSYS FLUENT CFD software. The findings indicate that the Venturi effect did occur at the openings. Providing a confined area at the inlet may enhance the Venturi effect, thus increasing the indoor air velocity. Based on the investigated scenario, it is found that the highest indoor air velocity of $0.2 \mathrm{~m} / \mathrm{s}$ was achieved for the $75 \%$ opening size with $1.5 \mathrm{~m}$ projection. This value indicated enhancement as the outdoor air velocity near the inlet was around $0.14 \mathrm{~m} / \mathrm{s}$ only. The findings also indicate that the indoor air flow distribution of high air velocity focused more at the area of flow path between the inlet and outlet. The findings can be as guidance in enhancing the natural cross-ventilation in buildings especially that are located at the area where the wind speed is low. Nevertheless, the findings are limited to low-rise building with such opening configuration. Further study needs to be executed to determine the effects to other opening configurations and building heights.
\end{abstract}

Keywords: Cross-ventilation, Venturi effect, openings, air velocity, air flow distribution 
keluar. Hasil kajian boleh dijadikan panduan untuk meningkatkan pengudaraan semula jadi bangunan terutamanya yang terletak di kawasan yang mempunyai kelajuan angin rendah. Namun, hasil kajian adalah terhad kepada bangunan rendah yang mempunyai konfigurasi bukaan yang sama dengan kajian ini. Kajian lebih lanjut perlu dilakukan bagi mengenalpasti kesan terhadap pelbagai konfigurasi bukaan dan ketinggian bangunan.

Kata kunci: Pengudaraan silang, kesan Venturi, bukaan, halaju udara, pengagihan aliran udara

(C) 2020 Penerbit UTM Press. All rights reserved

\subsection{INTRODUCTION}

Energy consumption in building is one of the issues in built environment that is widely discussed. This is due to its effects that lead to the environmental issues such as climate change, pollution and many more. Energy in building is utilized for electrical appliances, lighting, ventilation, water heating and many others. The study by Shetabivash (2015) indicated that mechanical ventilation utilized about $30 \%$ of total energy consumption for residential buildings in developed countries [1]. Hence, one of the actions that can be employed in reducing the energy consumption in building is via the application of natural ventilation.

Natural ventilation is one of the passive strategies that helps to reduce the energy consumption in building. Another benefit of natural ventilation is its ability to reduce the indoor heat [2]. The studies by Amir et al. (2019) and Tong et al. (2019) had also shown that the indoor air temperature decreased in the condition where the windows were opened to allow for ventilation [3, 4]. However, natural ventilation is only effective for certain conditions such as for building with open layout plan, and located within the surrounding that has minimal air and noise pollutions [1].

Natural ventilation is driven by two main forces, which are the pressure differences and the air density differences. However, during the summer time, the natural ventilation via opening of low rise building mainly occurs due to pressure differences, which is wind driven ventilation [5]. The effective wind driven ventilation normally occurs in a cross-ventilated building that has openings located at different facade orientations. In addition to this, the opening configuration also affects the amount and distribution of the air flow [6].

The natural ventilation studies have been conducted by many researchers since long time ago. Among the methodologies used are experiment $[7,8]$, wind tunnel investigation $[9,10]$ and numerical simulation [1, 11, 12, 13]. Each method has its own advantages and drawbacks. There are many previous studies that investigated the openings significance to the indoor natural ventilation. Elshafei et al. (2017) investigated on the window parameters namely the size, placement and shade. The study indicated that the design modifications of the window parameters were able to improve the indoor thermal comfort. In this case, the window size was enlarged more than $50 \%$ from the original size [14].

The opening position, size $[1,6,15,16]$ and shape $[6,1]$ are significant in determining the flow characteristics inside the building, in which they influence the ventilation performance and indoor air quality. The average pressure coefficient (Cp) value and the air change rate/hour alter with the change of opening dimension due to the change in the obstruction to the air flow [6]. Tominaga and Blocken (2016) evaluated the air flow dispersion in a crossventilated building. The findings indicated that the opening positions had significant effects to the pollutant removal rate and the air flow profiles [15]. Nevertheless, this study focused on the opening position only, and excluded the effect of the size.

The study by Montazeri and Montazeri (2018) on the significance of the outlet opening for a building with a wind catcher had shown that the increase of window size, which was the inlet, was able to enhance the air flow rate into the building [16]. However, the study did not evaluate the effect of window size increment to the indoor air velocity. The enhancement of air flow rate due to the increase of opening size was also agreed by sacht and Lukiantchuki (2017). The study also stated that the incident wind angles of $0^{\circ}$ and $45^{\circ}$ produced more air flow rate compared to the wind angle of $90^{\circ}$ (parallel to the opening). Another interesting finding in this study was although the air flow rate was lower, the air velocity was higher in the case of smaller opening size. Nevertheless, the drawback was the high air velocity only occurred at certain region, while at the other regions, the air velocities were low [6].

Shetabivash (2015) examined the effects of opening position and shape on the cross ventilation. The shape used in the study was rectangular with different sizes. The findings showed that the inlet position and shape played important role in determining the indoor air flow [1]. However, it is found that the study employed uniform air velocity distribution at the inlet, in which this does not reflect the real condition, where the atmospheric boundary layer exists to form the wind profile. Gao and Lee (2011) had investigated the ventilation performance of various opening configurations at residential units in Hong Kong. The study defined the opening 
parameters to be the building orientation, as well as the window and door positions. The findings indicated that the opening positions that were opposite or perpendicular to each other performed better natural ventilation [11].

Though there are already many previous studies related to the building openings and their effects to the indoor ventilation, this study see the potential of modifying the opening size and configuration to enhance the indoor air velocity and flow distribution by introducing the Venturi effect.

For the hot and humid climate, the sufficient air velocity passing by the human body is significant in achieving thermal comfort. This is because in the hot and humid climate where the relative humidity of air is high, the air velocity is able to enhance the evaporative heat loss from the human body to the environment. The thermal comfort range for air temperature may also increase with the rise of air velocity [17]. The previous studies by Yusoff (2006) and Candido et al. (2011) suggested that the air velocity to achieve thermal comfort in hot and humid climate is $0.8 \mathrm{~m} / \mathrm{s}$ [18, 19]. Besides $0.8 \mathrm{~m} / \mathrm{s}$, Mihara et al. (2019) recommended the range between $0.9 \mathrm{~m} / \mathrm{s}$ to $1.8 \mathrm{~m} / \mathrm{s}$ to achieve thermal comfort in hot and humid climate [20]. The range was provided as the appropriate air velocity is also depending on the indoor air temperature. Previous studies indicated that for natural cross ventilation, the enlargement of opening results in the higher indoor air velocity [14, 21]. Meanwhile, the Venturi effect theory states that the air velocity increases when it passes through a constricted section or crosssectional area. Within this constricted area, the air pressure decreases while the air velocity increases [22].

The Venturi effect related to the air flow in or around buildings had been investigated by Blocken et al. (2008), Blocken et al. (2011), Van Hooff et al. (2011) and Van Hooff et al. (2012) [22, 23, 24, 25]. Blocken et al. (2008) investigated the Venturi effect that occurred at the converging and diverging passages between the buildings. The findings indicated that the Venturi effect was actually more significant in a confined space than unconfined space [22]. Meanwhile, Blocken et al. (2011) examined natural ventilation at a building with a Venturi-shaped roof. The results showed that the Venturi effect and the wind-blocking effect had influenced the performance of the studied roof. However, the Venturi effect was not at its greatest effect as the flow was unconfined [23]. Meanwhile, the Venturi-shaped roof with and without guiding vanes had been examined by Van Hooff et al. (2011) The study found that the roof without guiding vanes provided better performance than with the guiding vanes [24]. Other investigation related to Venturishaped roof was by Van Hooff et al. (2012), in which the study found that the roof performance was greater with the increase of building width [25].
Hence, the previous studies of Venturi effect show that with the right strategy, the Venturi effect may enhance the natural ventilation in building as it may increase the indoor air velocity. The increase of indoor air velocity is found to be favourable for hot and humid countries as it helps to enhance the indoor thermal comfort. Nevertheless, the challenge of achieving this high air velocity is to distribute and maintain such air velocity to the whole region of the space or room. This is because the high air velocity tends to occur only within the region where the inlet and outlet are located, while the other regions will experience low air velocity $[6,26]$.

Hence, is it possible to apply the Venturi effect for the building openings in enhancing the indoor air velocity, and at the same time providing good air flow distribution within the space? Due to that, the present research intends to examine the effects of various opening sizes and configurations to the indoor air velocity and flow distribution for a crossventilated building. In this study, the air flow is considered mainly due to the wind pressure, whereas the buoyancy induced ventilation is considered insignificant. This is due to the inlet and outlet opening locations in this study which are at the same level. The buoyancy induced ventilation becomes important only if the height between the inlet and outlet openings has significant difference [27]. The findings of this study are of paramount important especially for the buildings that are located at the area where the wind speed is low such as the urban area.

\subsection{METHODOLOGY}

The methodologies used in this paper are field measurement and numerical simulation. The purpose of field measurement is for the validation of numerical simulation steps and procedures in ensuring the reliability of the results. Meanwhile, the numerical simulation is executed in investigating the air flow dispersion and velocity for various opening sizes and configurations. Numerical simulation is selected as this method is cost and time savings compared to the experiment. It is important to note that the study focuses solely on the wind driven natural ventilation, and excludes the buoyancy induced ventilation.

\subsection{Field Measurement}

The field measurement was executed at a single zone cross-ventilated building, which is a heritage mosque named as Masjid Tanah (Tanah Mosque). A single-zone building refers to a building that has one indoor area, with no internal wall that divides the space inside it. As the openings are located at the front and side facades which allow for natural cross 
ventilation to occur, hence, the mosque is considered as a single zone cross-ventilated building.

The mosque is located at a suburban area in the district of Alor Gajah, Melaka, Malaysia. It is an old mosque, constructed in the year of 1800s, and had gone through a renovation in 1951 (Figure 1). The mosque was selected because it has the criteria of single zone cross-ventilated building, which is required in this study. Its simple layout plan, with many openings around, has allowed the natural cross-ventilation to occur (Figure 2).

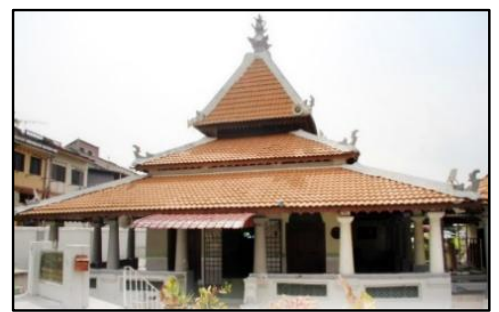

Figure 1 Masjid Tanah that is located in the district of Alor Gajah, Melaka, Malaysia

The measuring tools utilized in the field measurement were two multi-parameter ventilation meters namely TSI Velocicalc 9565 series (Figure 3). The tools were positioned at the indoor and outdoor of the mosque. They were placed at the height of 1.2 $\mathrm{m}$ from the ground level, which is within the height of human level. Besides ensuring the ability of measuring air velocity, their locations at the indoor and outdoor areas were selected based on the safety reason, as well as no interruption to the users of the mosque. Prior to conducting the field measurement, they were calibrated by placing them parallel to each other, and at the height of $1 \mathrm{~m}$ from the ground level. The results of the calibration indicated that the percentage of discrepancies between the air velocity readings of the two measuring tools was $4 \%$.

The tools have the air velocity measurement accuracy of $\pm 0.015 \mathrm{~m} / \mathrm{s}$. However, they have restriction in the air flow direction, which they can only measure the air velocity from the direction where the sensors are facing. In this study, the indoor air velocity sensor was placed to face the main entrance of the mosque (as shown in Figure 2). Therefore, the outdoor air velocity sensor was made to face the similar direction. For the purpose of numerical simulation validation, the field measurement was executed for two days only in the end of March 2018. The duration for the measurement was seven hours, which was from 9 am to $4 \mathrm{pm}$. March was selected as it is among the warmest months in Malaysia. Meanwhile, the measurement was conducted until 4 pm only as during the measurement days, the rain occurred in the late afternoon, which was after 4 pm. The outdoor wind velocity and the indoor air velocity data were recorded every five minutes interval.

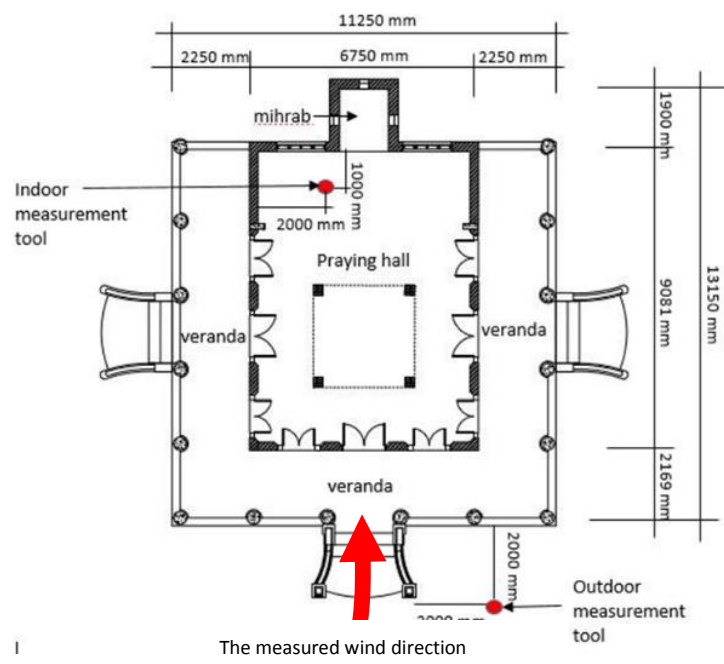

Figure 2 The layout plan of Masjid Tanah, the locations of the measuring tools and the measured wind direction

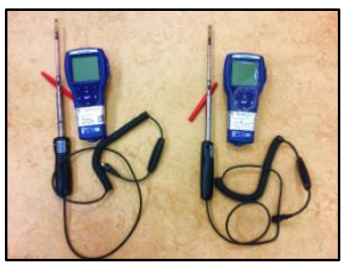

Figure 3 The multi-parameter ventilation meters, TSI Velocicalc 9565 series

The mosque is located at the suburban area, where it is surrounded by low rise buildings. The average wind velocities recorded during the field measurement were low, which the highest was only $0.35 \mathrm{~m} / \mathrm{s}$. Meanwhile, the indoor air velocities recorded at the point where the measuring tool was located were also low, which were lower than 0.1 $\mathrm{m} / \mathrm{s}$ (Table 1). These values are lower than $0.8 \mathrm{~m} / \mathrm{s}$, which is the recommended air velocity for thermal comfort in hot and humid climate $[18,19]$. Due to that, it is found that the mosque is currently being ventilated by both, the mechanical fans and the airconditioner. This is a normal situation in Malaysia, especially in urban or suburban area where the wind speed is usually low. The easiest and fastest solution normally opted is by using the mechanical ventilation, though it is not environmental friendly and energy saving. Hence, it is essential in this study to investigate the potential of enhancing the indoor air velocity via passive means. 
Table 1 Average outdoor wind velocities and indoor air velocities

\begin{tabular}{lcc}
\hline Time & $\begin{array}{c}\text { Average wind velocity } \\
(\mathbf{m} / \mathbf{s})\end{array}$ & $\begin{array}{c}\text { Average indoor air } \\
\text { velocity }(\mathbf{m} / \mathbf{s})\end{array}$ \\
\hline $9 \mathrm{am}$ & 0.24 & 0.07 \\
$10 \mathrm{am}$ & 0.29 & 0.08 \\
$11 \mathrm{am}$ & 0.26 & 0.09 \\
$12 \mathrm{pm}$ & 0.32 & 0.07 \\
$1 \mathrm{pm}$ & 0.35 & 0.08 \\
$2 \mathrm{pm}$ & 0.35 & 0.05 \\
$3 \mathrm{pm}$ & 0.35 & 0.08 \\
$4 \mathrm{pm}$ & 0.24 & 0.07 \\
\hline
\end{tabular}

\subsection{Numerical Simulation}

The numerical simulation software used in this study was ANSYS FLUENT 2019 R1. Before executing the investigations, the numerical simulation was validated initially with the field measurement. Upon reaching good agreement between the numerical simulation and field measurement results, the investigations were executed in three stages. The reason for conducting three stages of simulations are elaborated in the section of results and discussion. The building measured in the field measurement was constructed in this simulation. However, the building had been simplified in reducing the simulation time, as shown in Figure 4. The building simplification had also been executed in the previous studies $[12,26,29$, 30] with the similar reason.

\subsubsection{Computational Domain, Boundary Condition and Solver Setting}

The numerical simulation employed a steady-state air flow through a three-dimensional model. The air flow at the inlet of the computational domain was set to have an atmospheric boundary layer (ABL) wind profile, with the exponent (a) of 0.28, which represents the suburban condition (Figure 5). This condition was similar to the site condition of the building in the field measurement. The power law equation used for the $A B L$ wind profile is as below:

$$
\frac{y}{y_{\text {ref }}}=\left(\frac{z}{z_{\text {ref }}}\right)^{a}
$$

where $y$ is the wind speed $(\mathrm{m} / \mathrm{s})$ at height $Z(\mathrm{~m})$, while $y_{r e f}$ is the wind speed $(\mathrm{m} / \mathrm{s})$ at height $z_{r e f}(\mathrm{~m})$. In this study, the RANS turbulence model was also employed, which was Realizable k-epsilon model. The intensity was set to be $5 \%$. The Realizable kepsilon model was also utilized by Stavrakakis et al. (2008) in the simulation of natural ventilation [30].

The dimensions of the computational domain were set based on the best practice suggested in the previous studies $[12,16,26,33]$. The dimensions of the windward and leeward distances were based on the building height $(\mathrm{H})$. The windward distance was set to be five times of the height $(5 \mathrm{H})$, while the leeward distance was ten times of the height $(10 \mathrm{H})$. The overall dimensions of the computational domain are depicted in Figure 5, while the details of the boundary condition are demonstrated in Table 2 .

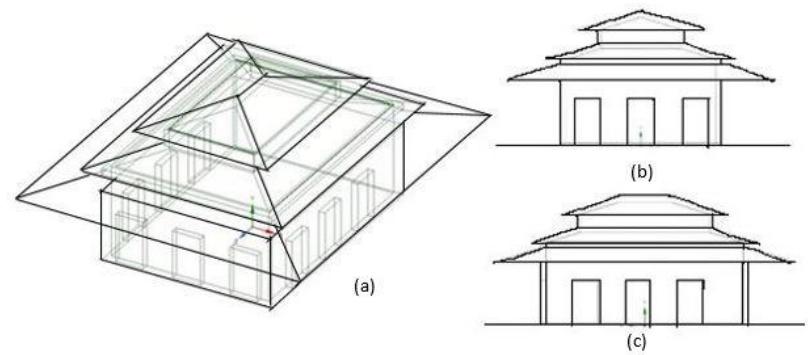

Figure 4 The simplified building model, (a) isometric view, (b) front view, (c) side view

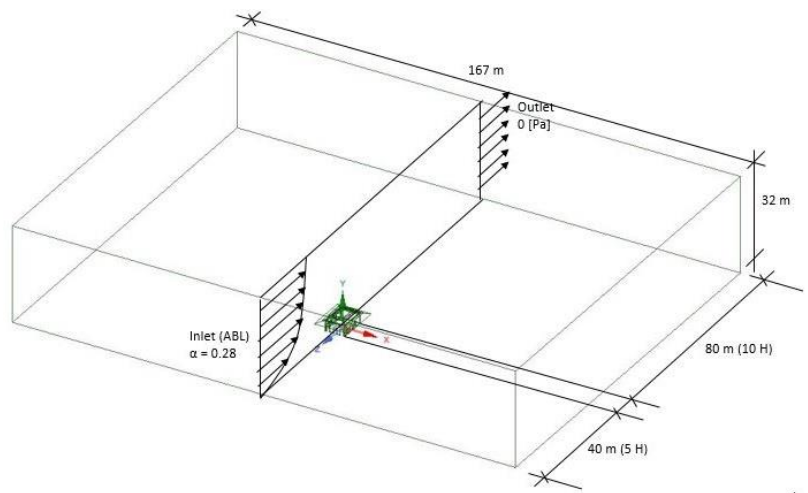

Figure 5 The overall dimensions of computational domain and the boundary conditions

Table 2 The details of the boundary condition

\begin{tabular}{|c|c|c|}
\hline Boundary & Type & Details \\
\hline Ground surface & Wall & $\begin{array}{l}\text { No slip shear condition } \\
\text { with roughness constant } \\
\text { of } 0.5\end{array}$ \\
\hline Top surface & Symmetry & - \\
\hline $\begin{array}{l}\text { East and west } \\
\text { wall surfaces }\end{array}$ & Symmetry & - \\
\hline $\begin{array}{l}\text { North } \\
\text { surface }\end{array}$ & Inlet & $\begin{array}{l}\text { Velocity magnitude : } y= \\
0.24 \mathrm{~m} / \mathrm{s}\left(\frac{z}{1.2 \mathrm{~m}}\right)^{0.28} \\
\text { Turbulent intensity: } 5 \% \\
\text { Turbulent viscosity ratio: } \\
10\end{array}$ \\
\hline $\begin{array}{l}\text { South } \\
\text { surface }\end{array}$ & Outlet & $\begin{array}{ll}\text { Gauge } & \text { pressure } \\
\text { (pascal): } 0 & \\
\text { Backflow } & \text { turbulent } \\
\text { intensity: } 5 \% & \\
\text { Backflow } & \text { turbulent } \\
\text { viscosity ratio: } 10\end{array}$ \\
\hline Building surfaces & Wall & $\begin{array}{l}\text { No slip shear condition } \\
\text { with roughness constant } \\
\text { of } 0.5\end{array}$ \\
\hline
\end{tabular}


The $A B L$ wind profile was set at the inlet of the computational domain, where the reference wind velocity (yref) and the reference height (Zref) were similar to the measured wind velocity and height during the field measurement. As mentioned in the field measurement section, the measuring tools utilized have the restriction where they can only measure the air velocity from the direction where the sensors are facing. Hence, for the validation process, the wind angle was made similar to the direction measured in the field measurement. This direction was set to be $0^{\circ}$ in the numerical simulation. However, for the simulation of opening sizes and configurations, the wind direction was set to be at $90^{\circ}$ wind angle in order to allow for the natural cross ventilation to occur. The number of iterations set for the simulation was 1000.

\subsubsection{Grid Independence Test}

Grid independence study was performed to determine the most appropriate numbers and sizes of elements for the numerical simulation. The type of mesh used in this study was tetrahedron mesh (Figure 6), in which it was also utilized by other previous studies $[12,32,33]$ in the investigations of natural ventilation. The body of influence (BOI) method was utilized at the proximity area of the building model, where the meshes at this area were refined further compared to the other areas in the domain.

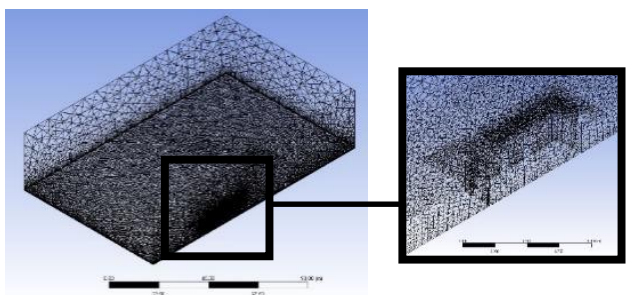

Figure 6 Tetrahedron mesh used in the numerical simulation

Comparison of results was made between the numerical simulation and the field measurement. In this case, the air velocity results derived at 9 am during the field measurement were compared. The number of elements compared, and the results derived are demonstrated in Table 3. As mentioned before, the elements within $\mathrm{BOI}$ method area were refined further compared to the other areas. Hence, for each grid tested, the element sizes were $0.7 \mathrm{~m}$ and $1.5 \mathrm{~m}$ for Grid 1, $0.5 \mathrm{~m}$ and $1 \mathrm{~m}$ for Grid 2, and 0.3 $\mathrm{m}$ and $0.5 \mathrm{~m}$ for Grid 3. For each grid, the smaller element size refers to $\mathrm{BOI}$ method area, while the larger size refers to other areas than $\mathrm{BOI}$ method area.
Table 3 Comparison of three different numbers of elements

\begin{tabular}{lccccc}
\hline \multicolumn{1}{c}{ Type } & $\begin{array}{c}\text { No.of } \\
\text { element }\end{array}$ & $\begin{array}{c}\text { NS } \\
{[\mathrm{m} / \mathrm{s}]}\end{array}$ & $\begin{array}{c}\text { FM } \\
{[\mathrm{m} / \mathrm{s}]}\end{array}$ & $\begin{array}{c}\text { DV } \\
{[\mathrm{m} / \mathrm{s}]}\end{array}$ & $\begin{array}{c}\text { DP } \\
{[\%]}\end{array}$ \\
\hline $\begin{array}{l}\text { Grid 1: } \\
\text { Coarse }\end{array}$ & 768,576 & 0.067 & 0.070 & 0.003 & 4 \\
$\begin{array}{l}\text { Grid 2: } \\
\text { Medium }\end{array}$ & $1,297,726$ & 0.071 & 0.070 & 0.001 & 1 \\
$\begin{array}{l}\text { Grid 3: } \\
\text { Fine }\end{array}$ & $3,284,991$ & 0.075 & 0.070 & 0.005 & 7 \\
\hline
\end{tabular}

Note: NS (Numerical simulation), FM (Field measurement), DV (Discrepancy value), DP (Discrepancy percentage)

The air velocity value measured at 9 am during the field measurement was $0.07 \mathrm{~m} / \mathrm{s}$. The grid independent test indicated that Grid 2 provided the smallest discrepancy percentage compared to the air velocity derived in the field measurement, which was $1 \%$ (Table 3). By considering the computing time, as well as the accuracy of the results, the computational grid selected for this study was Grid 2.

\subsubsection{Locations of Measuring Points}

There were two conditions for the locations of measuring points, namely the location for the validation of numerical simulation, and the locations for the investigations of air velocity and air flow distribution. Prior to conducting the investigations of the air flow and velocity, the steps and procedures of the numerical simulation were validated against the field measurement. Hence, for the validation process, the measuring point was placed at the similar location as in the field measurement (Figure 7(a)). Meanwhile, for the air flow and velocity investigations, the measuring points were positioned at nine locations namely the inlets (Points A, B and C), the indoor areas (Points 1, 2 and 3) and the outlets (Point D, E and F), as shown in Figure $7(\mathrm{~b})$. The reason of positioning the measuring points at these locations was to examine the velocity values for the incoming air at the inlets, the air when it was distributed within the indoor area, and the outgoing air at the outlets.

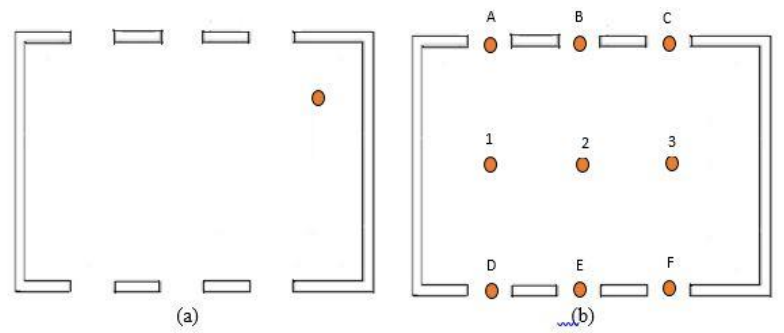

Figure 7 The locations of measuring points for a) validation process, b) numerical simulations of air flow and velocity 


\subsubsection{Validation of Numerical Simulation}

The numerical simulation was validated against field measurement in ensuring the reliability of the simulation results. This practice had been executed by many previous studies $[11,12,30]$. In the validation process, the input data of the environmental conditions and the building model developed in the numerical simulation were made similar to the field measurement. However, the building model was simplified in reducing the simulation time.

Figure 8 demonstrates the comparison of results between the numerical simulation and field measurement. The validation results indicated that the deviation percentages were around $20 \%$ and less except at $12 \mathrm{pm}$ and $2 \mathrm{pm}$. Though the deviation percentages for $12 \mathrm{pm}$ and 2 pm were more than 20 $\%$, but the differences in the air velocity results were small actually, which were 0.02 and $0.05 \mathrm{~m} / \mathrm{s}$, respectively. The deviation percentages of $20 \%$ and less were considered acceptable and had been employed by previous studies such as Gao \& Lee (2011) and Muhsin et al. (2017) [11, 12]. Hence, in overall, the validation indicated good agreement between the field measurement and numerical simulation results.

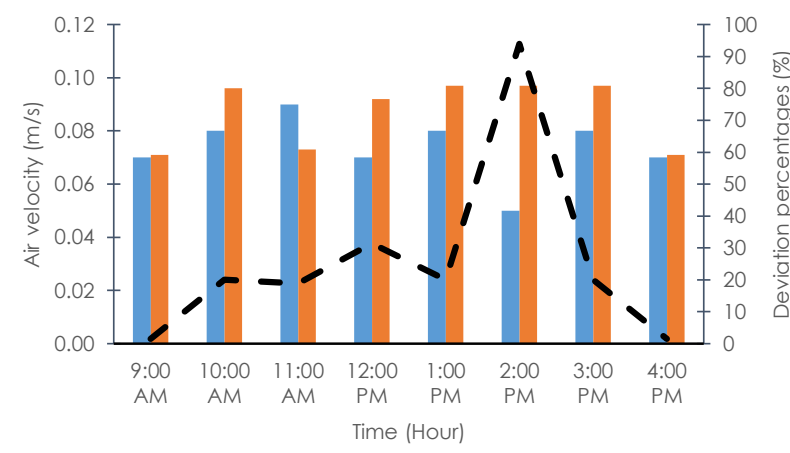

Field measurement results Numerical simulation results

- - deviation percentages

Figure $\mathbf{8}$ The comparison of results between the numerical simulation and field measurement for validation

\subsubsection{Opening Sizes and Configurations}

The opening sizes investigated in this research were modified from the base case model that used the rectangular shape with $100 \%$ opening size. The modifications were executed with the reference to the percentages of the opening sizes. The investigations started with the $100 \%\left(1.98 \mathrm{~m}^{2}\right)$ opening size, and followed by $75 \%\left(1.50 \mathrm{~m}^{2}\right), 50 \%$ $\left(0.99 \mathrm{~m}^{2}\right)$ and $25 \%\left(0.50 \mathrm{~m}^{2}\right)$ of opening sizes (Figure 9). The reason for the reductions in the percentages was to examine the Venturi effect to the indoor air velocity and air flow distribution.

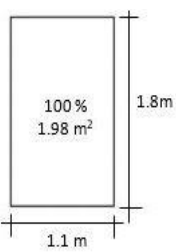

(a)

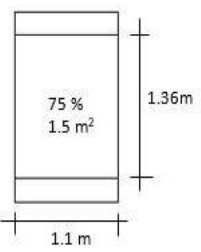

(b)

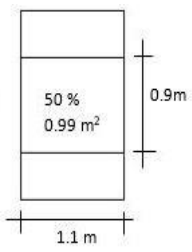

(c)

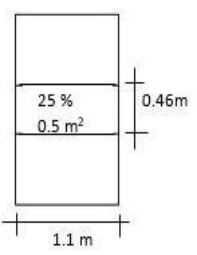

(d)
Figure 9 The percentages of opening sizes: (a) $100 \%$, (b) 75 $\%$, (c) $50 \%$, and (d) $25 \%$

Besides the reductions in the opening sizes, other configuration examined in this study was the opening with projection. The reason of incorporating projection at the opening was to provide a confined space to enhance the Venturi effect. This is in conjunction with the recommendation by Blocken et al. (2008) and Blocken et al. (2011) that the Venturi effect was more significant in a confined space $[22,23]$. There were two sizes of projection lengths namely $1 \mathrm{~m}$ and $1.5 \mathrm{~m}$ (Figure 10). The projection configuration was designed to be like a small horizontal shaft in enhancing the Venturi effect. For the projection of $1.5 \mathrm{~m}$ length, the additional $0.5 \mathrm{~m}$ was built inward of the inlet opening as to minimize the projection length at the outward building façade. A long projection at the outward façade is impractical as it may provide obstruction to the outdoor activities. Nevertheless, it is also not advisable to have a projection of more than $0.5 \mathrm{~m}$ length at the inner wall as it may also interrupt the indoor activities. Due to that reason, the length of the projection examined in this study was limited to $1.5 \mathrm{~m}$.

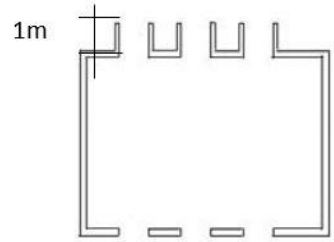

(a)

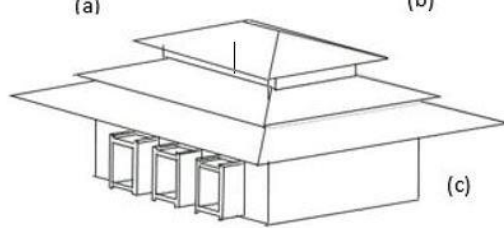

Figure 10 The (a) plan view of $1 \mathrm{~m}$ length projection, (b) plan view of $1.5 \mathrm{~m}$ length projections, and (c) isometric view

\subsection{RESULTS AND DISCUSSION}

The investigations on the effects of opening sizes to the air flow distribution and velocity were conducted for wind speed of $0.24 \mathrm{~m} / \mathrm{s}$, and wind direction of $90^{\circ}$. This is the lowest wind speed recorded during the field measurement. The reason of utilizing the lowest wind speed at the site is to simulate the worst condition. The ability of enhancing natural ventilation 
at the worst condition will definitely provide better results for the other conditions. The numerical simulations were executed in three stages. The first stage was the openings with similar sizes of inlets and outlets, the second stage was the openings with smaller inlets sizes compared to the outlets, while the last stage was the simulation of similar openings conditions in stage two, but with the addition of projections.

\subsection{Openings with Similar Sizes of Inlets and Outlets}

The initial investigations were executed for $100 \%$ opening size which was similar to the condition in the field measurement. As mentioned before, the measuring points in the numerical simulation were located at nine different locations which were the inlets (Points A, B and C), the indoor areas (Points 1, 2 and 3 ) and the outlets (Point D, E and F), as shown in Figure 7 (b).

The comparison of air velocity contours at $1 \mathrm{~m}$ height from the floor level are depicted in Figure 11 Figure 11 indicate that $100 \%$ opening size provided the best air velocity distribution inside the building as the areas with air velocity of lower than $0.06 \mathrm{~m} / \mathrm{s}$ were the least compared to other opening sizes. The air velocity contours in Figure 11 (a) indicate that for $100 \%$ opening size, the air velocity near the inlets was around $0.14 \mathrm{~m} / \mathrm{s}$. The air velocity value increased when it passed through the inlets. The air velocity values recorded for $100 \%$ opening size were $0.20 \mathrm{~m} / \mathrm{s}$ at point $A, 0.21 \mathrm{~m} / \mathrm{s}$ at point $B$ and $0.21 \mathrm{~m} / \mathrm{s}$ at point C. However, the air velocity decreased when it flowed within the room, and increased again when passing via the outlets. For $100 \%$ opening size, the recorded air velocities at the indoor areas (points 1, 2 and 3) were $0.11 \mathrm{~m} / \mathrm{s}, 0.04 \mathrm{~m} / \mathrm{s}$ and $0.11 \mathrm{~m} / \mathrm{s}$, respectively. Meanwhile, the average indoor air velocity recorded at $1 \mathrm{~m}$ height from the floor level was $0.20 \mathrm{~m} / \mathrm{s}$.

Hence, the results for $100 \%$ opening size showed that the air velocity was able to be increased when it passed via a constricted area, which in this case was the opening. This indicated that the Venturi effect did occur at the inlet openings. However, would the similar effect occur or improve if the opening sizes reduced? Due to that, more investigations were conducted in examining whether the air velocities increase with the reduction of opening sizes. Further simulations were executed for $75 \%\left(1.5 \mathrm{~m}^{2}\right), 50 \%$ $\left(0.99 \mathrm{~m}^{2}\right)$ and $25 \%\left(0.5 \mathrm{~m}^{2}\right)$ opening sizes in comparison to the original $100 \%$ opening size which was $1.98 \mathrm{~m}^{2}$. The results on the investigations of the opening size reductions are also depicted in Figures 11 and 12. These figures demonstrate the air velocity contours and values for all the opening sizes in comparison to $100 \%$ opening size.

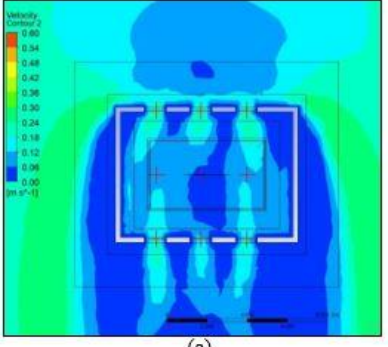

(a)

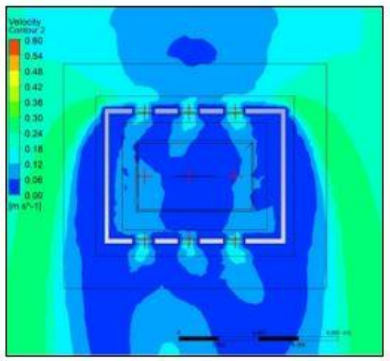

(c)
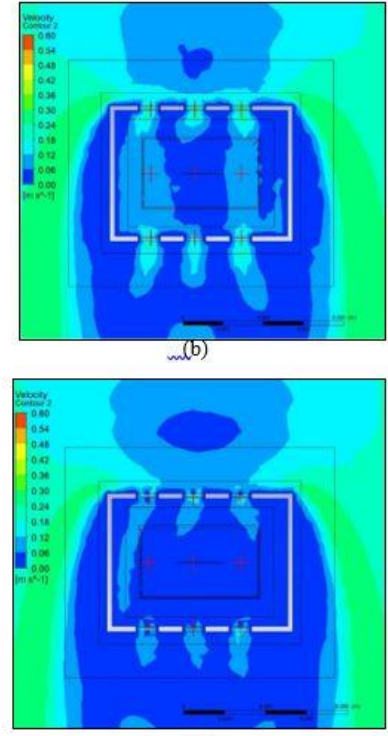

(d)
Figure 11 The plan view of air velocity contours for a) $100 \%$, b) $75 \%$, c) $50 \%$, and d) $25 \%$ opening sizes

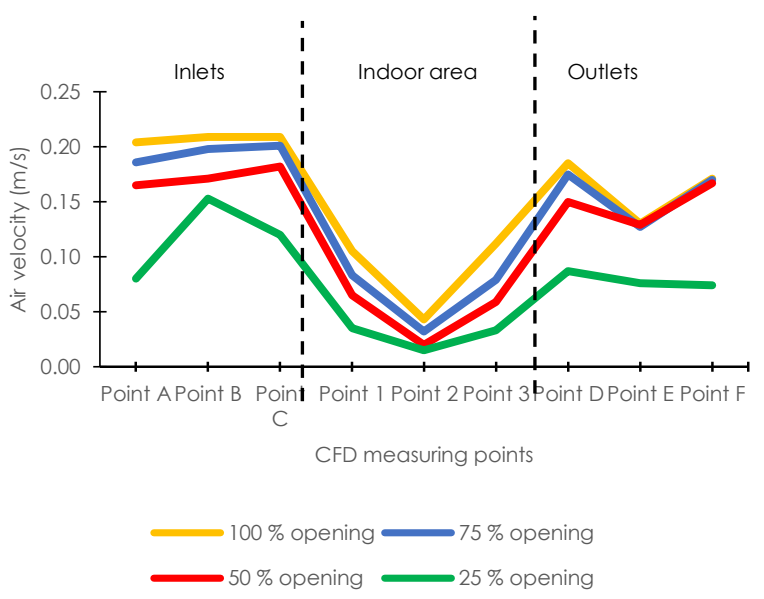

Figure 12 The air velocity values at nine different locations for $100 \%, 75 \%, 50 \%$ and $25 \%$ opening sizes

The overall results in Figures 11 and 12 show that $100 \%$ opening size provided the highest air velocity values at all points, as well as the greatest air flow distribution of high air velocity values. The investigations also indicated that there was no enhancement of air velocities for the reduction of openings sizes. Moreover, lower air velocities were recorded for smaller opening sizes. This is in corresponding to the recommendation by Elshafei et al. (2017) and Givoni (1994) where larger opening size resulted in higher indoor air velocity [14, 21]. Nevertheless, is there any way of increasing the indoor air velocity for a small opening size? 


\subsection{Openings with Smaller Inlets Sizes Compared to Outlets, and Addition of Projections}

Consequent from the results derived, other strategies were examined in enhancing the indoor air velocity. Though the previous investigations indicated that the $100 \%$ opening size resulted in the highest air velocity values at all points, reduction of opening size was implemented for the strategies that were further examined. The reason was to resemble the real situation where in building, normally only the door has the full height opening, while smaller opening is usually found in window. As natural ventilation usually occurs via window, further investigations in this study had considered the opening size for window. Hence, the opening sizes further investigated were $75 \%, 50 \%$ and $25 \%$.

The investigated strategies were as follows: 1) smaller inlet size compared to outlet, and 2) incorporated projection at the inlet to create a horizontal shaft for enhancing Venturi effect. For the strategy 1, the investigated inlets had the opening sizes of $75 \%, 50 \%$ and $25 \%$, while the opening size for the outlets was remained $100 \%$. Strategy 1 was proposed, as according to Givoni (1994) the indoor air velocity increased if the inlet size was smaller than the outlet size [21]. Meanwhile, for the strategy 2, it was stated in the previous study that the projection such as the wing wall increased the indoor air velocity [34]. Two projection sizes were examined, which were $1 \mathrm{~m}$ and $1.5 \mathrm{~m}$ lengths.
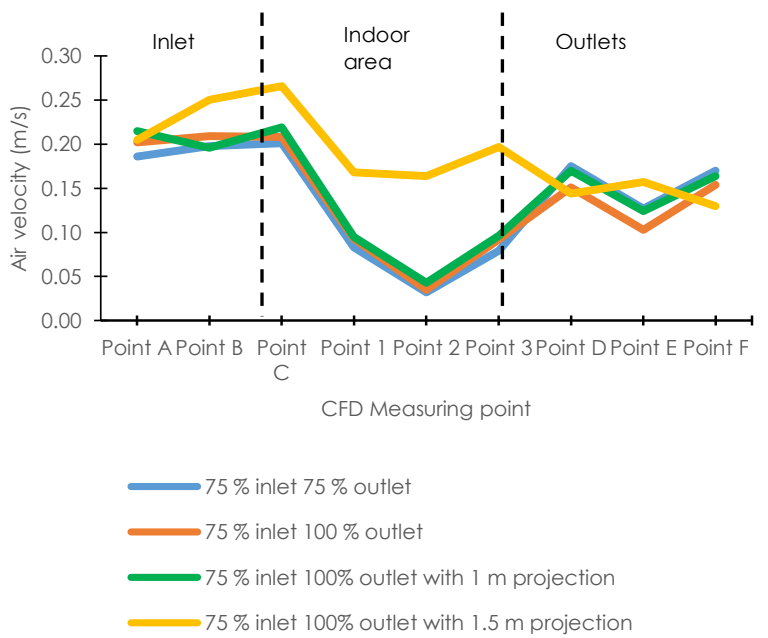

Figure 13 The air velocity values at nine different locations for various strategies of $75 \%$ inlet openings

Figures 13, 14 and 15 demonstrate the air velocity values at nine different locations for various strategies of $75 \%, 50 \%$ and $25 \%$ inlet openings, respectively. In these figures, besides the results of simulations stage 2 and 3 , comparisons were also made with the simulation stage 1 results, where the inlets and outlet were similar sizes. From the figures, it is found that for all opening sizes, the highest air velocities were derived for the inlet openings with 1.5 meter projections, except for $25 \%$ opening strategies where the results were varying. Nevertheless, for the $25 \%$ opening strategies, it is found that the presence of $1.5 \mathrm{~m}$ projection was able to provide the highest air velocities at the indoor area, namely at points 1,2 and 3. Hence, the results showed that the Venturi effect was enhanced further with the presence of confined spaces, which were the projections at the openings. This finding is in correspondent to the study by Blocken et al. (2008) [22]. The results also demonstrated that the longer the confined space, the greater was the Venturi effect. Consequently, higher indoor air velocities were achieved.

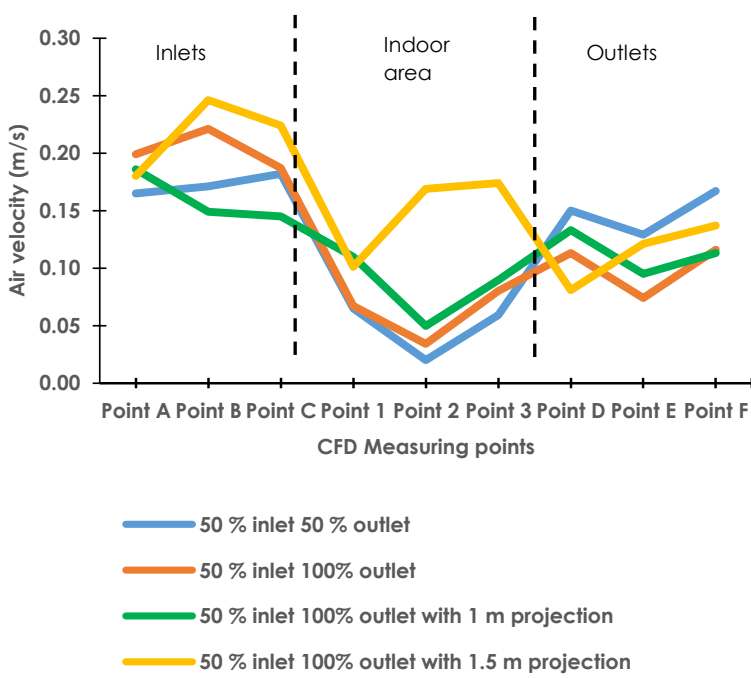

Figure 14 The air velocity values at nine different locations for various strategies of $50 \%$ inlet openings
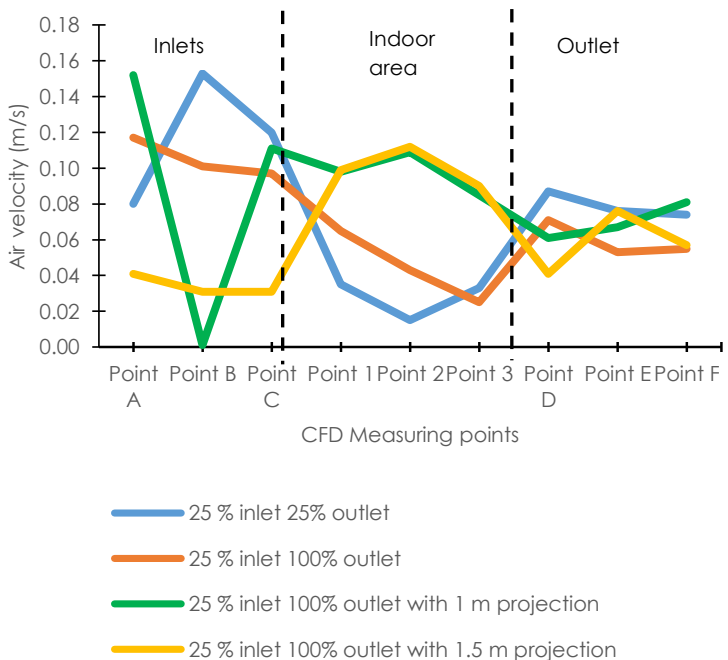

Figure 15 The air velocity values at nine different locations for various strategies of $25 \%$ inlet openings

Due to the effective strategy of $1.5 \mathrm{~m}$ projection at the inlet opening, comparative analysis was further executed for such strategy. Figure 16 depicts 
the air velocity values at nine different locations for $75 \%, 50 \%$ and $25 \%$ inlet openings with 1.5 meter projections while Figure 17 shows the air velocity contours for such strategies. It is found that the strategy of $75 \%$ inlet opening with $1.5 \mathrm{~m}$ projection provided the highest air velocity values at most of the points (Figure 16). In addition, this strategy also provided the greatest indoor air velocity distribution compared to the other inlet opening sizes (Figure 17).
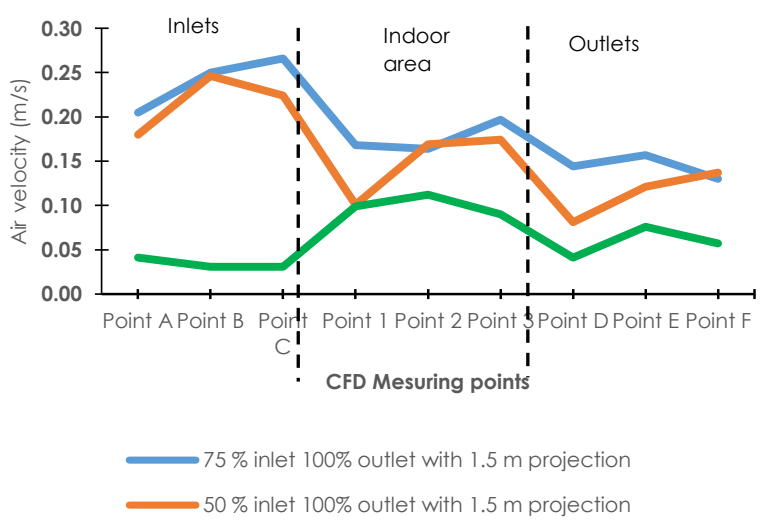

$25 \%$ inlet $100 \%$ outlet with $1.5 \mathrm{~m}$ projection

Figure 16 The air velocity values at nine different locations for $75 \%, 50 \%$ and $25 \%$ inlet openings with 1.5 meter projections

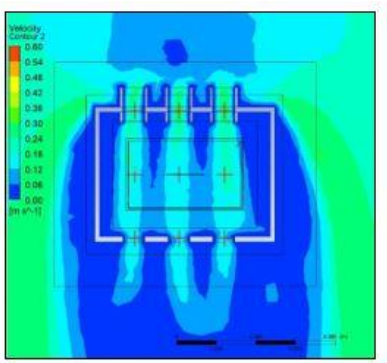

(a)

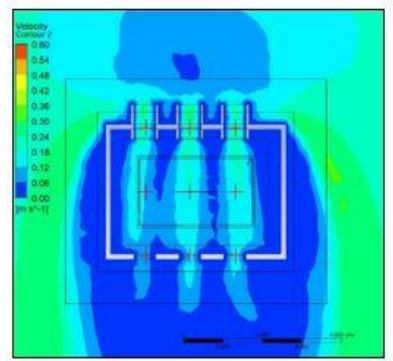

(b)

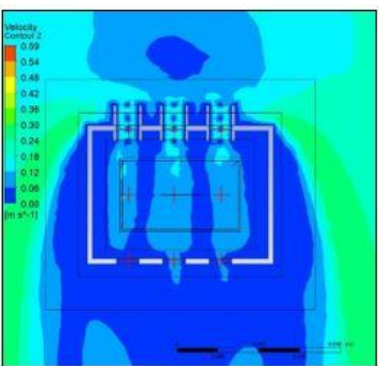

(c)

Figure 17 The plan view of air velocity contours for a) $75 \%$ inlet opening with $1.5 \mathrm{~m}$ projection, b) $50 \%$ inlet opening with $1.5 \mathrm{~m}$ projection, and c) $25 \%$ inlet opening with $1.5 \mathrm{~m}$ projection

\subsection{CONCLUSION}

This study investigated the air flow distribution and velocity for different opening sizes and configurations. The opening sizes examined were 100
$\%$ (1.98 m2), $75 \%(1.5 \mathrm{~m} 2), 50 \%(0.99 \mathrm{~m} 2)$ and $25 \%$ (0.5 m2), while the opening configurations studied were rectangular shape with $1 \mathrm{~m}$ and $1.5 \mathrm{~m}$ projections. In this study, the outdoor wind velocity was set to be $0.24 \mathrm{~m} / \mathrm{s}$, which was the lowest velocity recorded during the field measurement. Meanwhile, the wind direction investigated was $90^{\circ}$ only as this study is intended to derive the initial idea on enhancing the indoor air velocity and flow distribution by incorporating Venturi effect strategy. The effects of other wind angles will be investigated in the future research. From the investigations, it is found that the Venturi effect did occur at the inlets as there were increment in the air velocity values. However, the air velocities reduced when they approached the indoor area, and increased again at the outlets. Nevertheless, the overall findings indicate the followings:

- The larger the opening size, the greater is the air velocity and air flow distribution at the indoor area.

- $\quad$ The smaller inlet size compared to outlet may increase the indoor air velocity.

- The presence of projection which functions as a horizontal shaft at the inlet may increase the indoor air velocity as it enhances the Venturi effect. The longer the projection, the higher is the indoor air velocity.

- Larger opening size provides greater air flow distribution of high air velocities at the indoor area.

- The air velocity contours show that the high air velocities at the indoor area seem to be concentrated at the air flow paths between the inlets and outlets. Areas farther than these flow paths suffer lower air velocities.

It is recommended in the future research to investigate more various configurations of inlets, as well as the effects of various wind angles to the indoor air flow distribution and velocity. It is also recommended to examine the effects to various building heights. With the right strategies, the projections at the inlets may enhance the Venturi effect, and consequently increase the indoor air velocity. However, besides enhancing the indoor air velocity, further studies need to be conducted in improving the indoor air flow distribution. It is hoped that the findings from this study are able to improve the natural cross-ventilation in buildings especially that are located at the area where the outdoor wind speed is low.

\section{Acknowledgement}

The author would like to thank Universiti Kebangsaan Malaysia and Ministry of Education Malaysia for funding the research via research grants GUP-2019- 
017 and FRGS/1/2019/TK10/UKM/02/4, respectively. The author would like to thank also the architecture students of UKM. They are Nur Anis Syuhadah, Syazani, Nurfaridatul Atira, Sya'ida Nurin, Khairul Anwar, Muhamad Naimmi, Nurul Huda Al-Ameen, and Mohd Hanif, who helped in producing the drawings of Masjid Tanah.

\section{References}

[1] H. Shetabivash. 2015. Investigation of Opening Position And Shape on the Natural Cross Ventilation. Energy and Buildings. 93: 1-15. https://doi.org/10.1016/j.enbuild.2014.12.053.

[2] X. Huang, X. Ma, and Q. Zhang. X. Huang, X. Ma, and Q. Zhang. 2019. Effect of Building Interface Form on Thermal Comfort in Gymnasiums lin Hot and Humid Climates. Frontiers of Architectural Research. 8(1): 32-43. https://doi.org/10.1016/j.foar.2018.11.002.

[3] A. Amir, M. F. Mohamed, M. K. A. M. Sulaiman, and W. F. M. Yusoff. 2019. Assessment of Indoor Thermal Condition of A Low-cost Single Storey Detached House: A Case Study in Malaysia. International Journal of Sustainable Tropical Design Research and Practice. 12(1): 80-88.

[4] S. Tong, N. H. Wong, E. Tan, and S. K. Jusuf. 2019. Experimental Study on the Impact of Facade Design on Indoor Thermal Environment in Tropical Residential Buildings. Building and Environment. 166: 106418. https://doi.org/10.1016/j.buildenv.2019.106418.

[5] N. Khan, Y. Su, and S. B. Riffat. 2008. A Review on Wind Driven Ventilation Techniques. Energy and Buildings. 40(8): 1586-1604. https://doi.org/10.1016/j.enbuild.2008.02.015.

[6] H. Sacht and M. A. Lukiantchuki. 2017. Windows Size and the Performance of Natural Ventilation. Procedia Engineering. 196: 972-979. https://doi.org/10.1016/j.proeng.2017.08.038.

[7] W. F. M. Yusoff, E. Salleh, N. M. Adam, A. R. Sapian, and M. Yusof Sulaiman. 2010. Enhancement of Stack Ventilation in Hot and Humid Climate Using a Combination of Roof Solar Collector and Vertical Stack. Building and Environment. 45(10): 2296-2308. https://doi.org/10.1016/j.buildenv.2010.04.018.

[8] D. H. Han, S. Kim, J. H. Choi, Y. S. Kim, H. S. Chung, H. Jeong, N. Watjanatepin, C. Ruangpattanawiwat, and S. H. Choi. 2018. Experimental Study on Thermal Buoyancyinduced Natural Ventilation. Energy and Building. 177: 111. https://doi.org/10.1016/j.enbuild.2018.07.046

[9] L. Ji, H. Tan, S. Kato, Z. Bu, and T. Takahashi. 2011. Wind Tunnel Investigation on Influence of Fluctuating Wind Direction on Cross Natural Ventilation. Building and Environment. 46(12): 2490-2499.

https://doi.org/10.1016/j.buildenv.2011.06.006.

[10] H. Sacht, L. Bragança, M. Almeida, and R. Caram. 2016. Study of Natural Ventilation in wind Tunnels and Influence of the Position of Ventilation Modules and Types of Grids on a Modular Façade System. Energy Procedia. 96: 953-964.

https://doi.org/10.1016/j.egypro.2016.09.173.

[11] C. F. Gao and W. L. Lee. 2011. Evaluating the Influence of Openings Configuration on Natural Ventilation Performance of Residential Units in Hong Kong. Building and Environment. 46(4): 961-969.

https://doi.org/10.1016/j.buildenv.2010.10.029.

[12] F. Muhsin, W. F. M. Yusoff, M. F. Mohamed, and A. R. Sapian. 2017. CFD Modeling of Natural Ventilation in a Void Connected to the Living Units of Multi-storey Housing for Thermal Comfort. Energy and Buildings. 144: 1-16. https://doi.org/10.1016/j.enbuild.2017.03.035.
[13] W. F. M. Yusoff, A. R. Sapian, E. Salleh, N. M. Adam, Z. Hamzah, and M. H. H. Mamat. 2014. Using Computational Fluid Dynamics in the Determination of Solar Collector Orientation and Stack Height of a Solar Induced Ventilation Prototype. Pertanika Journal of Science and Technology. 22(1): 273-288.

[14] G. Elshafei, A. Negm, M. Bady, M. Suzuki, and M. G. Ibrahim. 2017. Numerical and Experimental Investigations of the Impacts of Window Parameters on Indoor Natural Ventilation in a Residential Building. Energy and Buildings. 141: 321-332. https://doi.org/10.1016/j.enbuild.2017.02.055.

[15] Y. Tominaga and B. Blocken. 2016. Wind Tunnel Analysis of Flow and Dispersion in Cross-ventilated Isolated Buildings: Impact of Opening Positions. Journal of Wind Engineering and Industrial Aerodynamics. 155: 74-88. https://doi.org/10.1016/j.jweia.2016.05.007.

[16] H. Montazeri and F. Montazeri. 2018. CFD Simulation of Cross-ventilation in Buildings Using Rooftop Windcatchers: Impact of Outlet Openings. Renewable Energy. 118: 502-520.

https://doi.org/10.1016/j.renene.2017.11.032.

[17] L. A. López-Pérez, J. J. Flores-Prieto, and C. Ríos-Rojas. 2019. Adaptive Thermal Comfort Model for Educational Buildings in a Hot-Humid Climate. Building and Environment. 150: 181-194. https://doi.org/10.1016/j.buildenv.2018.12.011.

[18] W. F. M. Yusoff. 2006. The Relationship between the Air Velocity and the People's Comfort in Hot and Humid Climate of Malaysia. Master Thesis. University of Wales, Cardiff.

[19] C. Cândido, R. de Dear, and R. Lamberts. 2011. Combined Thermal Acceptability and Air Movement Assessments in a Hot Humid Climate. Building and Environment. 46: 379-385.

https://doi.org/10.1016/j.buildenv.2010.07.032.

[20] K. Mihara, C. Sekhar, Y. Takemasa, B. Lasternas, and K. W. Tham. 2019. Thermal Comfort and Energy Performance of a Dedicated Outdoor Air System with Ceiling Fans in Hot and Humid Climate. Energy and Buildings. 203: 109448.

https://doi.org/10.1016/j.enbuild.2019.109448

[21] B. Givoni. 1994. Passive Low Energy Cooling of Buildings. New York: John Wiley \& Sons, Inc.

[22] B. Blocken, P. Moonen, T. Stathopoulos, F.ASCE., and J. Carmeliet. 2008. A Numerical Study on the Existence of the Venturi-effect in Passages Between Perpendicular Buildings. Journal of Engineering Mechanics. 134(12): 1021-1028. 9399(2008)134:12(1021)

[23] B. Blocken, T. van Hooff, L. Aanen, and B. Bronsema. 2011. Computational Analysis of the Performance of a Venturi-shaped Roof for Natural Ventilation: Venturieffect Versus Wind-blocking Effect. Computers and Fluids. 48(1): 202-213.

https://doi.org/10.1016/j.compfluid.2011.04.012.

[24] T. van Hooff, L. Aanen, and B. Bronsema. 2011. A Venturishaped Roof for Wind-induced Natural Ventilation of Buildings: Wind Tunnel and CFD Evaluation of Different Design Configurations. Building and Environment. 46(9): 1797-1807. https://doi.org/10.1016/j.buildenv.2011.02.009.

[25] T. van Hooff, B. Blocken, L. Aanen, and B. Bronsema. 2012. Numerical Analysis of the Performance of a Venturi-shaped Roof for Natural Ventilation: Influence of Building Width. Journal of Wind Engineering and Industrial Aerodynamics. 104-106: 419-427. https://doi.org/10.1016/j.jweia.2012.02.013.

[26] W. F. M. Yusoff, M. K. A. M. Sulaiman, and F. Muhsin. 2019. Preliminary Evaluation of Air Flow in Atrium of Building in Hot and Humid Climate. International Journal of Sustainable Tropical Design Research and Practice. 12(1): 43-52.

[27] H. Awbi. 2003. Ventilation of Buildings. 2nd ed. London: 
Spon Press.

[28] F. Muhsin, W. Mohammad Yusoff, M. Mohamed, and A. Sapian. 2016. The Effects of Void on Natural Ventilation Performance in Multi-Storey Housing. Buildings. 6(3): 1-19. https://doi.org/10.3390/buildings6030035.

[29] W. F. M. Yusoff, A. R. Sapian, E. Salleh, N. M. Adam, and S. Johar. 2015. Application of Solar-induced Ventilation Prototype in Small and Medium Enterprise Building. Indoor and Built Environment. 24(3): 384-400. https://doi.org/10.1177/1420326X13512143.

[30] G. M. Stavrakakis, M. K. Koukou, M. G. Vrachopoulos, and N. C. Markatos. 2008. Natural Cross-ventilation in Buildings: Building-scale Experiments, Numerical Simulation and Thermal Comfort Evaluation. Energy and Building. 40(9): 1666-1681.

https://doi.org/10.1016/j.enbuild.2008.02.022.

[31] Y. Tominaga, A. Mochida, R. Yoshie, H. Kataoka, T. Nozu, M. Yoshikawa, T. Shirasawa. 2008. AlJ Guidelines for
Practical Applications of CFD to Pedestrian Wind Environment around Buildings. Journal of Wind Engineering and Industrial Aerodynamics. 96: 1749-1761. https://doi.org/10.1016/j.jweia.2008.02.058.

[32] J. O. P. Cheung and C. H. Liu. 2011. CFD Simulations of Natural Ventilation Behaviour in High-rise Buildings in Regular and Staggered Arrangements at Various Spacings. Energy and Buildings. 43(5): 1149-1158. https://doi.org/10.1016/j.enbuild.2010.11.024

[33] T. G. Farea, D. R. Ossen, S. Alkaff, and H. Kotani. 2015 CFD Modeling for Natural Ventilation in a Lightwell Connected to Outdoor through Horizontal Voids. Energy and Buildings. 86: 502-513.

https://doi.org/10.1016/j.enbuild.2014.10.030

[34] C. M. Mak, J. L. Niu, C. T. Lee, and K. F. Chan. 2007. A Numerical Simulation of Wing Walls Using Computationa Fluid Dynamics. Energy and Buildings. 39(9): 995-1002. https://doi.org/10.1016/j.enbuild.2006.10.012 